\title{
Stenosis aorta dengan penyulit hiperkalemia
}

\author{
Rika Permata Sari ${ }^{1}$, Yerizal Karani ${ }^{2}$, Citra Kiki Krevani ${ }^{3}$ \\ 1. RSI Ibnu Sina, Pekanbaru; 2. Bagian Kardiologi dan Kedokteran Vaskular, Fakultas Kedokteran, \\ Universitas Andalas; 3. RSUP dr. M. Djamil, Padang
}

Korespondensi: Rika Permata Sari, email: rikaabdi@gmail.com

\begin{abstract}
Abstrak
Stenosis Aorta (SA) merupakan salah satu kelainan katup jantung yang sering ditemui, dan juga merupakan indikasi untuk dilakukannya operasi penggantian katup. Kalium adalah ion ekstraselular berperan penting dalam pengaturan elektrofisiologis fungsi miokard. Hiperkalemia dapat dikaitkan dengan kelainan elektrokardiografi yang sering terjadi. Secara umum, hiperkalemia menghasilkan penurunan kecepatan rangsangan dan konduksi secara bertahap pada sel pacu jantung dan jaringan di seluruh jantung. Tujuan: Memaparkan mengenai stenosis aorta baik secara diagnostik maupun penatalaksanaan. Kasus: Wanita 79 tahun dengan keluhan utama pusing setelah aktivitas. Nyeri dada tidak menjalar saat aktivitas dan berkurang saat istirahat sejak satu minggu sebelumnya. Riwayat nyeri dada sejak 1 tahun terakhir saat aktivitas dan tidak muncul saat istirahat. Sesak nafas muncul 7 hari rawatan, tidak menciut, tidak dipengaruhi makanan atau cuaca, terutama saat nyeri dada. Pasien didiagnosis stenosis aorta berat dengan hiperkalemia. Simpulan: Berdasarkan manajemen stenosis aorta, pasien direncanakan angiografi. Jika ada penyumbatan koroner disarankan Coronary Artery Bypass Grafting sekaligus penggantian katup aorta.
\end{abstract}

Kata kunci: stenosis aorta; hiperkalemia; kelainan elektrokardiografi

\section{Abstract}

Aortic stenosis is one of the frequent valvular heart diseases, and an indication of valve replacement surgery. Potassium is an extracellular ion and play a vital role in the electrophysiologic function of the myocard. Hyperkalaemia is associated with frequent electrocardiogram disorder. In general, hyperkalaemia produces a gradual decrease of stimulation and conduction in the myocard and whole heart tissue. Objectives: Describes aortic stenosis both diagnostic and management. Case: A 79-yearold woman with a major complaint is dizzy after activity. Chest pain didn't spread during activity and decreased at rest in the last week. History of chest pain in the last 1 year during activity and didn't appear at rest. Shortness of breath appeared 7 days of treatment, no wheezing, didn't affect by food or weather, especially when chest pain appeared. The patient was diagnosed with severe aortic stenosis with hyperkalaemia. Conclusions: Based on the management of aortic stenosis, patient was planned for angiography. If there was a coronary blockage, Coronary Artery Bypass Grafting and aortic valve replacement were recommended.

Keywords: aortic stenosis; hyperkalemia; electrocardiogram disorder 


\section{PENDAHULUAN}

Stenosis Aorta (SA) merupakan salah satu kelainan katup jantung yang sering ditemui, dan juga merupakan indikasi untuk dilakukannya operasi penggantian katup. Di Eropa dan Amerika Utara, SA terutama ditemui dalam bentuk SA kalsifikasi pada orang dewasa tua (2-7\% populasi berusia $>65$ tahun). ${ }^{1}$

Dalam berbagai studi epidemiologi mengidentifikasikan faktor risiko stenosis aorta sama pada aterosklerosis seperti merokok, gender pria, hipertensi, peningkatan kolesterol, diabetes dan gagal ginjal. ${ }^{2}$ Pengendalian terhadap faktor risiko tersebut menjadi langkah awal untuk pencegahan penyakit stenosis aorta. Namun banyak pasien dengan SA didiagnosis saat adanya murmur sistolik atau dilakukan ekokardiografi transtorakal saat pemeriksaan penyakit lain. ${ }^{4}$ Untuk menentukan derajat keparahan SA memang harus menggunakan modalitas ekokardiografi. Prognosis SA tergantung dari nilai peak aortic valve velocity, mean aortic valve gradient, aortic valve area, serta gejala dan tanda yang didapatkan dalam pemeriksaan. ${ }^{4}$

Laporan kasus ini bertujuan untuk memaparkan mengenai stenosis aorta baik secara diagnostik maupun penatalaksanaan.

\section{LAPORAN KASUS}

Seorang wanita berusia 79 tahun datang ke IGD RSUP Dr. M. Djamil dengan pusing seperti akan pingsan 2 hari sebelum masuk rumah sakit, muncul saat beberapa lama setelah aktivitas. Riwayat pusing sebelumnya ada, sekitar 7 hari yang lalu. Riwayat pingsan tidak ada. Riwayat berdebar-debar tidak ada.

Nyeri dada dirasakan saat aktivitas dan berkurang dengan istirahat 7 hari sebelum masuk rumah sakit, nyeri terasa berat pada dada kiri dengan durasi kurang dari 20 menit, tidak dapat ditunjuk dengan satu jari dan tidak menjalar. Keluhan tidak disertai dengan keringat dingin, mual, ataupun muntah. Riwayat nyeri dada sebelumnya diakui sejak 1 tahun terakhir dengan keluhan lebih ringan dan hanya muncul saat aktivitas seperti berjalan jauh atau mencuci. Keluhan nyeri dada yang muncul saat istirahat atau tidur tidak ada.

Pasien juga mengeluh sesak nafas sejak 7 hari SMRS, tidak menciut, tidak dipengaruhi makanan ataupun cuaca. Sesak makin terasa saat nyeri dada. Sesak lebih berkurang dengan posisi duduk, namun masih dapat tidur terlentang. Riwayat sesak saat beraktivitas diakui sejak 7 bulan yang lalu seperti menaiki tangga dan berjalan jauh. Riwayat terbangun malam karena sesak dan riwayat sesak ketika perubahan posisi secara cepat disangkal. Riwayat bengkak kaki juga disangkal.

Pasien mempunyai riwayat hipertensi tapi tidak rutin kontrol. Pasien tidak mempunyai riwayat diabetes melitus, kolesterol tinggi maupun merokok. Saat ini pasien sudah menopause. Riwayat keluarga yang mempunyai sakit jantung tidak ada. 
Pasien dengan riwayat perawatan di RS Swasta di Padang 4 hari sebelum masuk rumah sakit, dikatakan menderita sakit jantung dan mendapatkan obat Spironolakton $1 \times 25 \mathrm{mg}$, Bisoprolol 1x5mg, Amlodipin $1 \times 5 \mathrm{mg}$, Alprazolam $1 \times 0,5 \mathrm{mg}, \mathrm{Na}$ Diclofenac 2x50m, Ranitidin 2x150mg, Loratadine $1 \times 10 \mathrm{mg}$, Terbutaline Sulfat 2x2,5mg, Trihexypenidil $\mathrm{HCl} 2 \times 6 \mathrm{mg}$. Pasien tidak mendapatkan obat suntik di perut selama dirawat di rumah sakit. Pasien juga pernah dirawat di rumah sakit yang sama dengan keluhan yang sama 7 bulan sebelum masuk rumah sakit, mendapatkan obat yang sama.

Kini pasien dirujuk dari salah satu RS Swasta dengan diagnosis kerja AV Block derajat II tipe II, mendapatkan IVFD RL + Dopamin 1 ampul dengan kecepatan 8 tetes per menit, Sulfas Atropin 2 ampul.

Pada pemeriksaan fisik didapatkan keadaan umum sedang, kesadaran komposmentis, berat badan $50 \mathrm{~kg}$, tinggi badan $150 \mathrm{~cm}$, tekanan darah 140/50 $\mathrm{mmHg}$, nadi $51 \mathrm{kali} /$ menit, pernafasan 22 kali/menit, dan suhu $36,8^{\circ} \mathrm{C}$. pada pemeriksaan mata tidak ditemukan sklera ikterik atau konjungtiva anemis. Pada leher Jugular Vena Pressure setinggi $5+0 \mathrm{cmH} 2 \mathrm{O}$.
Pulsasi arteri karotis teraba lemah dan terlambat dibandingkan dengan impuls apek jantung. Pada pemeriksaan dinding dada untuk paru didapatkan bentuk dan gerak dinding dada simetris, fremitus dada kiri sama dengan dada kanan, sonor pada kedua lapang paru, dan tidak didapatkan rhonki basah halus atau kasar di lapang paru. Pada pemeriksaan jantung ditemui iktus kordis tidak terlihat, iktus kordis teraba 1 jari ke lateral dari linea midclavicularis sinistra dan ruang interkostalis $\mathrm{VI}$, batas atas ruang jantung pada ruang interkostalis II, batas kanan jantung pada garis parasternal kanan, batas kiri jantung pada 1 jari lateral linea midclavicularis sinistra, dan batas bawah jantung pada ruang intercostalis $\mathrm{VI}$, bunyi katup jantung S1 normal, S2 komponen aorta (A2) melemah, murmur sistolik tipe ejeksi grade 3/6 punctum maximum di upper right sternal border ruang interkostalis II-III dengan penjalaran ke apek. Pada pemeriksaan abdomen didapatkan bising usus dalam batas normal, tak tampak distensi, hepar dan spleen tak teraba. Ekstremitas dengan akral hangat dan tidak ditemukan edema.

Berikut gambaran EKG pada pasien ini:

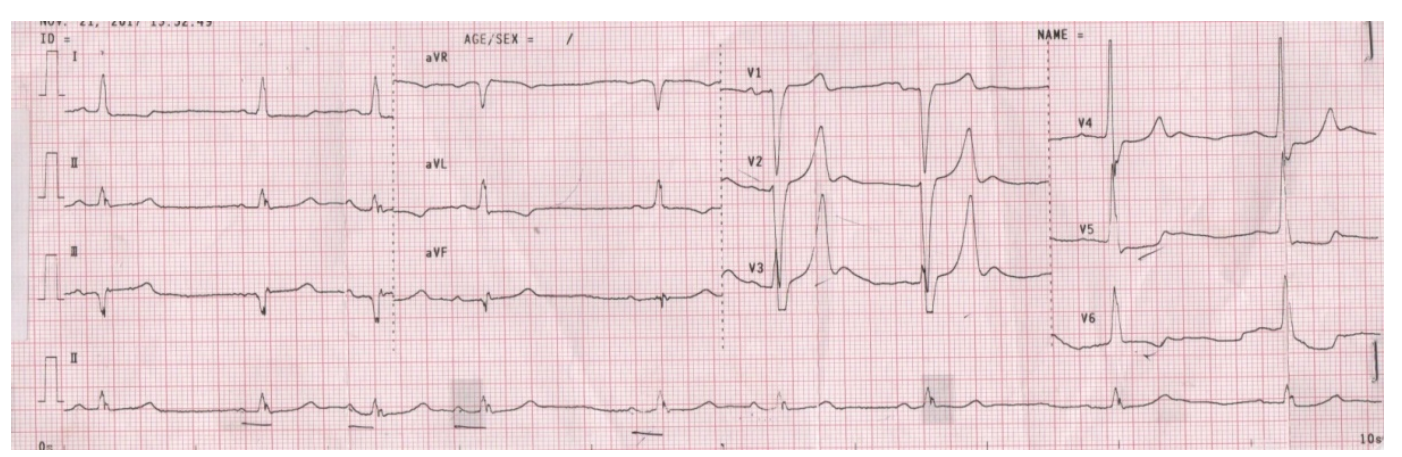

Gambar 1. Elektrokardiogram 
Didapatkan gambaran irama sinus, laju QRS 60 kali/menit, axis LAD, gelombang $P$ normal, PR int 0,16 detik, durasi QRS 0,06 detik, ST depresi horizontal di V4-V6, tall T di V2-V3, LVH (-), RVH (-), QTc 0,44 ms.

Dari monitor terlihat transient AV Blok derajat II tipe 2, sehingga dilakukan holter.

Nilai laboratorium didapatkan hasil sebagai berikut; hemoglobin 10,2 gr/dL, leukosit 9620/mm3, thrombosit 292000/mm3, hematokrit 31\%, ureum $27 \mathrm{mg} / \mathrm{dL}$, kreatinin $1,0 \mathrm{mg} / \mathrm{dL}$, creatinine clearance $36 \mathrm{~mL} / \mathrm{mnt}$, gula darah sewaktu 112 $\mathrm{mg} / \mathrm{dL}$, natrium $123 \mathrm{mmol} / \mathrm{L}$, kalium 6,1 $\mathrm{mmol} / \mathrm{L}$, chlorida $102 \mathrm{mmol} / \mathrm{L}$, kalsium 8,5 $\mathrm{mmol} / \mathrm{L}$, dan Troponin $\mathrm{l}<0,01 \mathrm{U} / \mathrm{L}$.

Gambaran Rontgen Thoraks AP didapatkan cardiothoracic ratio $68 \%$, segmen aorta tidak menonjol, segmen pulmonal tidak menonjol, pinggang jantung mendatar, apek tertanam, kranialisasi (-) dan infiltrate (-).

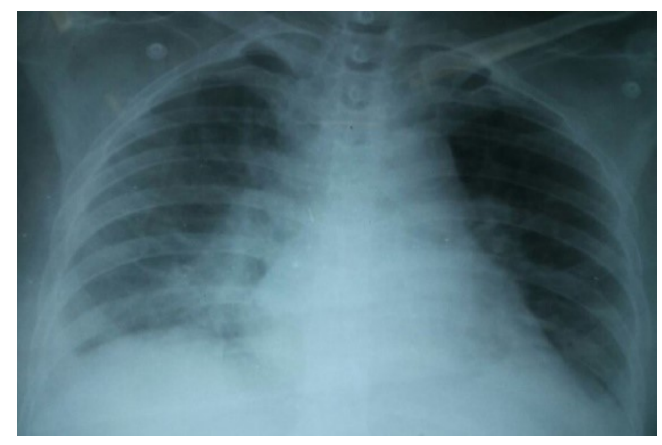

Gambar 2. Rontgen thoraks AP

Pasien dirawat di bangsal jantung dengan diagnosa kerja suspek stenosis aorta NYHA fc II, SA exit block dd/AV block derajat II tipe 2, sinus aritmia, hiperkalemia, hipertensi derajat 1, CHF fc // ec HHD, dan AKI RIFLE $R$ dd CKD stg III. Terapi yang diberikan pada awal perawatan adalah IVFD NaCL 0,9\% 500cc/24jam, 02 4L/mnt, bisoprolol 1×1,25 mg, kalitake $3 \times 1$ sachet, Ca glukonas $1 \mathrm{gr}$, furosemid $2 \times 20 \mathrm{mg} \mathrm{IV}$, insulin 10 IU dalam D40\% 50 cc. Direncanakan untuk ekokardiografi dan pemeriksaan profil lipid, fungsi faal hepar, magnesium dan asam urat.

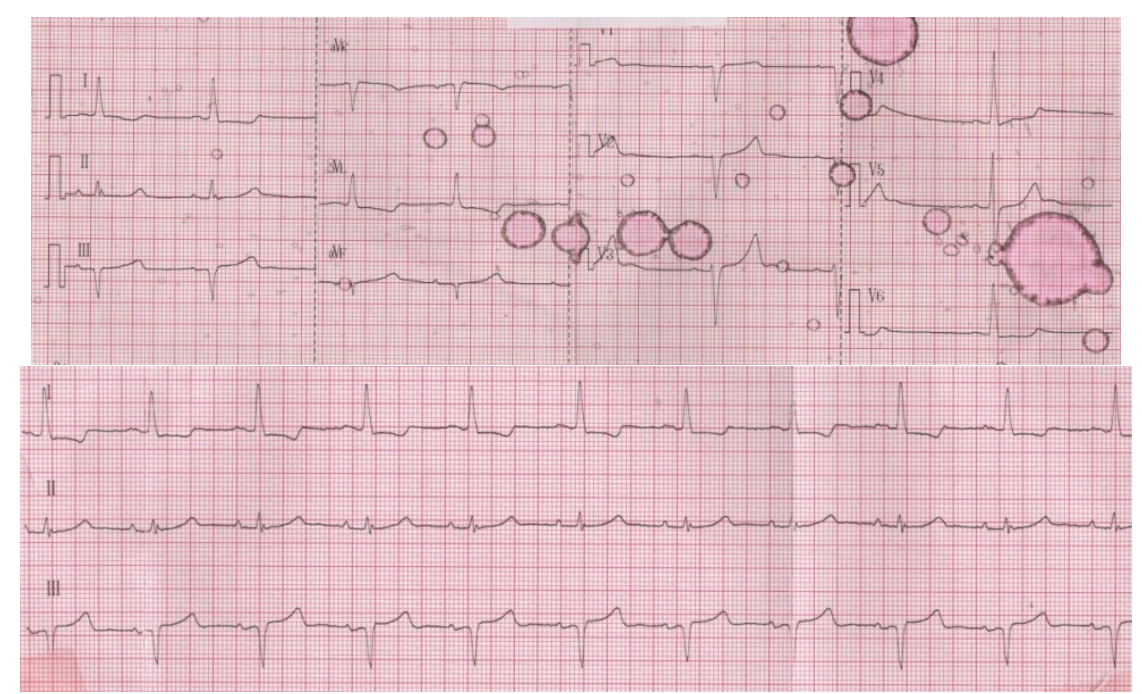

Gambar 3. EKG tanggal 22 November 2017

Pada hari rawatan ke-2, keluhan pusing dan sesak berkurang, tidak ada keluhan nyeri dada, dan hemodinamik stabil. Dilakukan ekokardiografi dengan hasil 
stenosis aorta berat, regurgitasi aorta ringan ec kalsifikasi degeneratif, regurgitasi mitral sedang, fraksi ejeksi 55\% (simpson), global normokinetik, kontraktilitas ventrikel kanan baik, E/A 0,9, LA dimensi $27 \mathrm{~mm}$, LV EDD $55 \mathrm{~mm}$, LV ESD $47 \mathrm{~mm}$, sec (-), trombus (-). Dimana pada pemeriksaan katup aorta didapatkan: 3 kuspis, kalsifikasi (+), fusi RCC, aortic valve area (AVA) 0,7 cm2 (planimetri), AVA 0.4 $\mathrm{cm} 2$ (VTI), mean AVG $52 \mathrm{mmHg}$, peak AVG $73 \mathrm{mmHg}$, aorta regurgitasi ringan DT 0,3 $\mathrm{cm} / \mathrm{s}$, PHT 1100 ms, dan regurgitasi mitral sedang. Katup-katup lain baik.

Hasil laboratorium pada hari rawatan ke-2 adalah total kolesterol $155 \mathrm{mg} / \mathrm{dL}$, HDL-C 36 mg/dL, LDL-C 92 mg/dL, trigliserida 132 $\mathrm{mg} / \mathrm{dL}$, SGOT $11 \mathrm{U} / \mathrm{L}$, SGPT $4 \mathrm{U} / \mathrm{L}$, magnesium 1,9 mg/dL, kalium 5,5 Mmol/L.

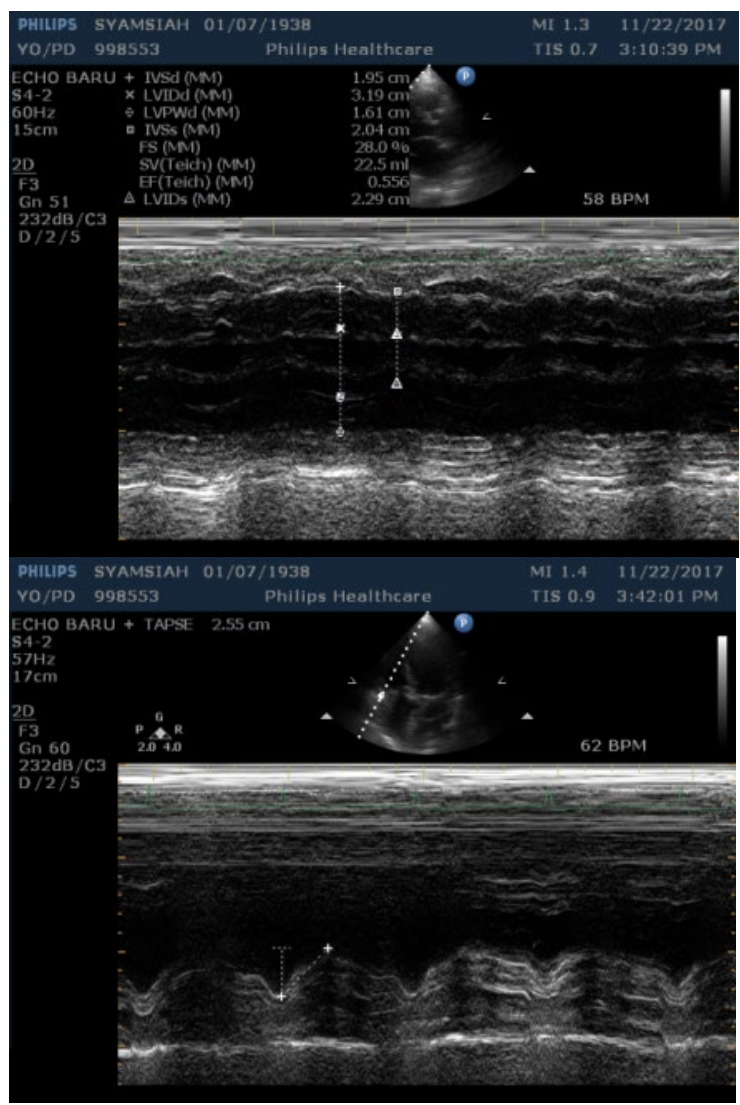

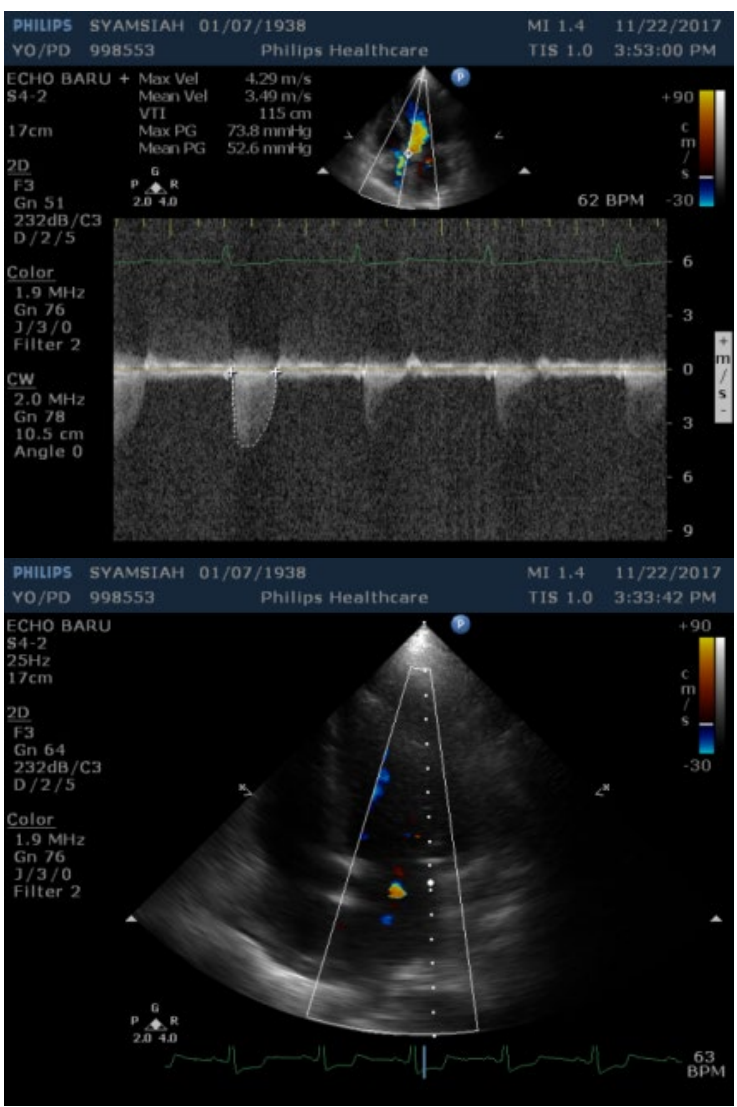

Gambar 4. Ekokardiogram

EKG hari rawatan ke-2 (22 November 2017) adalah sinus rhytm, laju QRS $72 \mathrm{x} /$ menit, axis $L A D$, gelombang $P$ normal, $P R$ Interval 0,20 detik, QRS durasi 0,08 detik, ST-T change (-), LVH (-), RVH (-), QTc 0.45 ms.

Diagnosis pasien ini menjadi aorta stenosis berat dan regurgitasi mitral sedang NYHA fc II, AV Blok derajat II tipe 2 sinus rhytm, hiperkalemia perbaikan.

Pada hari rawatan ke-3 klinis tampak perbaikan, berkurangnya keluhan sesak dan tidak ada keluhan nyeri dada, keadaan umum sedang dengan kesadaran komposmentis. Tanda vital untuk tekanan darah 140/50 mmHg, nadi 60 kali/menit, laju pernafasan $20 \mathrm{kali} / \mathrm{menit}$, dan suhu $36,5^{\circ} \mathrm{C}$. Tidak ditemukan rhonki pada 
kedua lapang paru. Pasien dilakukan Holter.

Pada hari rawatan ke-4, keadaan umum semakin membaik, tidak ada keluhan pusing, tidak ada sesak dan tidak ada keluhan nyeri dada, kesadaran komposmentis. Tanda vital untuk tekanan darah 140/50 mmHg, nadi $60 \mathrm{kali} / \mathrm{menit}$, laju pernafasan 20 kali/menit, dan suhu 36,5 oC. Hasil holter dengan irama dasar adalah sinus rhytm, AV conduction: $A V$ Block derajat II tipe II, chronotropic competence: baik, episode baradikardi tidak ada, episode takikardia tidak ada, ST$T$ changes: ST depresi down slopping dan $T$ inverted lead I, aVL, V5-V6, irama tambahan: PVC (+) infrequent, Qtc: 0,4270,391 ms.

Pasien diperbolehkan untuk rawat jalan dengan terapi pulang bisoprolol 1x1,25 mg, furosemide $1 \times 40 \mathrm{mg}$, Rencana selanjutnya adalah kontrol ke poli jantung 3 hari berikutnya. Dan pasien juga dianjurkan angiografi. Jika ada penyumbatan koroner akan disarankan CABG sekaligus penggantian katup aorta. Jika tidak ada penyumbatan koroner, akan disarankan untuk AVR. ${ }^{12}$

\section{PEMBAHASAN}

Keluhan utama pada pasien ini adalah pusing seperti akan pingsan (pre-syncope) yang muncul beberapa saat setelah aktivitas. Pada stenosis aorta berat dapat terjadi penurunan perfusi ke otak yang muncul pada saat aktivitas, yakni tekanan arteri menjadi turun akibat vasodilatasi sistemik dengan cardiac output yang cenderung tetap. ${ }^{4}$

Pada stenosis aorta terdapat obstruksi aliran darah menuju aorta sehingga ventrikel kiri harus menghasilkan tekanan yang lebih tinggi dibanding kondisi normal agar tetap dapat memompa darah melalui katup yang sempit, dengan kata lain stenosis aorta mengakibatkan beban tekanan berlebih pada ventrikel kiri (pressure overload). Kondisi ini menimbulkan perbedaan tekanan antara ventrikel kiri dengan aorta. Mekanisme kompensasi jantung terhadap kondisi patologis ini adalah dengan meningkatkan massa otot jantung (hipertrofi ventrikel kiri) untuk tetap dapat menghasilkan tekanan yang besar, akan tetapi mekanisme ini secara kronis juga memiliki efek yang tidak diinginkan. ${ }^{13}$

Peningkatan tekanan di ventrikel kiri akan meningkatkan tekanan pengisian ventrikel (ventricular filling pressure) sehingga tekanan di atrium kiri juga meningkat dan selanjutnya berdampak pada peningkatan tekanan di vena dan kapiler pulmonal dengan manifestasi klinis kongesti dan edema paru. Stenosis aorta juga menurunkan volume sekuncup jantung. Pada awal perjalanan penyakit, tubuh melakukan kompensasi dengan meningkatkan denyut jantung dan resistensi vaskular perifer sehingga curah jantung dan perfusi organ masih dapat dipertahankan, akan tetapi bila kapasitas mekanisme kompensasi ini sudah terlampaui curah jantung akan menurun yang berakibat pada penurunan perfusi 
organ termasuk perfusi ke otak dan menimbulkan sinkop, terutama saat aktivitas. Saat aktivitas terjadi penurunan resistensi perifer (vasodilatasi). Pada kondisi normal, jantung akan melakukan kompensasi dengan meningkatkan curah jantung sehingga perfusi tetap, akan tetapi pada stenosis aorta mekanisme kompensasi ini tidak adekuat sehingga timbul sinkop. ${ }^{13}$

Pasien juga mengeluh nyeri dada yang dirasakan saat aktivitas dan berkurang dengan istirahat. Nyeri dada ini dapat merupakan suatu angina tipikal atau akibat dari ketidaksesuaian demand dan supply oksigen. $^{1}$ Ketidaksesuaian antara supply dan demand aliran darah koroner juga dapat timbul pada stenosis aorta. Hipertrofi ventrikel dan denyut jantung yang tinggi meningkatkan demand sedangkan disisi lain menurunnya curah jantung dan memendeknya fase diastolik mengurangi perfusi koroner (supply). Tekanan di ventrikel kiri yang tinggi juga menekan kapiler koroner di endokardium, mengakibatkan perfusi ke jaringan berkurang. Oleh karena itu, pada pasien dengan stenosis aorta dapat timbul keluhan angina yang timbul terutama saat beraktivitas. ${ }^{13}$

Pasien juga mengeluh sesak nafas yang meningkat dengan aktivitas dan riwayat DOE sejak 7 bulan yang lalu. Sesak nafas ini bisa disebabkan oleh keadaan payah jantung ataupun gangguan fungsi diastolik atau sistolik ventrikel kiri lainnya. Pada pasien dengan stenosis aorta, sesak nafas dapat terjadi akibat disfungsi diastolik ventrikel kiri dengan peningkatan yang berlebih pada end diastolic pressure menyebabkan congesti pulmonal. Adanya paroxysmal nocturnal dyspnoea, orthopnoea, dan edema paru merefleksikan derajat hipertensi vena pulmonal. $^{4}$

Angina, dyspnoea on effort, dan presinkop atau sinkop merupakan karakteristik yang dapat ditemui pada stenosis aorta dan disebut sebagai trias stenosis aorta. Gejala tersebut pada umumnya muncul pada usia 50-70 tahun pada stenosis aorta dengan katup bikuspid dan pada usia di atas 70 tahun pada kalsifikasi stenosis aorta. ${ }^{4}$

Pada pemeriksaan fisik didapatkan tanda yang karakteristik adalah pulsasi maksimal arteri karotis yang teraba lemah dan terlambat (pulsus parvus et tardus) bila dibandingkan dengan impuls apek jantung. Palpasi arteri karotis dilakukan bersamaan dengan palpasi apek jantung dengan pulsasi maksimal arteri karotis yang menandakan ada hambatan aliran darah keluar dari ventrikel kiri. Pada kondisi normal, impuls apek jantung hampir bersamaan dengan pulsasi maksimal arteri karotis. ${ }^{11,13}$

Ditemukan adanya pembesaran jantung dengan pelebaran batas jantung ke kiri bawah. Adanya suara bising jantung sistolik tipe ejeksi pada right sternal border ruang intercostalis II-III bisa disebabkan oleh kelainan katup jantung seperti SA.

Pada pasien ini didapatkan hasil ekokardiografi sebagai berikut: stenosis aorta berat, regurgitasi aorta ringan ec 
kalsifikasi degeneratif, regurgitasi mitral sedang, fraksi ejeksi $55 \%$ (simpson), global normokinetik, kontraktilitas ventrikel kanan baik. Dimana pada pemeriksaan katup aorta didapatkan: 3 kuspis, kalsifikasi $(+)$, Fusi RCC, aortic valve area (AVA) 0,7 $\mathrm{cm} 2$ (planimetri), AVA $0,4 \mathrm{~cm}^{2}$ (VTI), mean AVG $52 \mathrm{mmHg}$, peak AVG $73 \mathrm{mmHg}$, aorta regurgitasi ringan DT 0,3 cm/s, PHT 1100 $\mathrm{ms}$, dan regurgitasi mitral sedang. Sesuai kriteria dari klasifikasi AHA, maka pasien ini tergolong pada symptomatic severe high gradient AS (D1). Dan berdasarkan 2017 ESC/EACTS Guidelines for the management of valvular heart disease maka pilihan tindakan untuk pasien ini adalah catheter aortic valve implantation (TAVI). Karena resiko operasi pasien ini $>4 \%$ berdasarkan Society of Thoracic Surgeons (STS) score.

Berdasarkan alur manajemen stenosis aorta dan 2017 ESC/EACTS Guidelines for the management of valvular heart disease, pasien ini direncanakan untuk angiografi. Jika dari hasil angiografi didapatkan ada penyumbatan pembuluh darah koroner jantung, disarankan AVR sekaligus CABG. Risiko operasi pada pasien ini jika dilakukan AVR sekaligus CABG berdasarkan STS Adult Cardiac Surgery adalah 4,162\%. Jika dari hasil angiografi tidak didapatkan penyumbatan pembuluh darah koroner jantung, disarankan untuk AVR. Risiko operasi pada pasien ini jika dilakukan AVR berdasarkan STS Adult Cardiac Surgery adalah 3,202\%.

Balloon aortic valvotomy (BAV) adalah suatu prosedur melebarkan penyempitan pada katup aorta dengan menggunakan balon transkateter. Metode ini serupa dengan yang sering dilakukan pada kasus stenosis mitral. Prosedur ini dapat dipertimbangkan sebagai terapi sementara pada pasien yang sebenarnya masih dapat dilakukan AVR tetapi kondisi saat ini belum memungkinkan untuk dilakukan operasi jantung dan untuk menstabilkannya dibutuhkan perbaikan hemodinamik dengan mengurangi derajat stenosis pada katup aorta atau sebagai terapi paliatif pada pasien dengan harapan hidup yang pendek. Prosedur BAV juga dapat digunakan sebagai terapi sementara pada pasien dengan stenosis aorta berat yang akan menjalani operasi lain yang mendesak dan diperkirakan pengurangan derajat stenosis aorta dapat menurunkan risiko operasi tersebut. ${ }^{13}$

Hiperkalemia bisa menyebabkan berbagai macam kelainan elektrokardiografi. Kalium adalah ion ekstraselular dengan peran penting dalam pengaturan elektrofisiologis fungsi miokard. Konsentrasi yang berbeda dari ion kalium intraseluler dan ekstraseluler yang tinggi dan kebalikannya untuk ion natrium, diatur oleh pompa sodium potassium adenosine triphosphatase (Na-K ATPase), sehingga menghasilkan potensial membran istirahat -90 $\mathrm{mV}$ di seluruh membran miosit. Akibatnya, setiap perubahan konsentrasi kalium ekstraselular memiliki pengaruh signifikan terhadap perubahan elektrofisiologis miosit. Hiperkalemia adalah gangguan elektrolit yang lazim dan berpotensi fatal. Insiden hiperkalemia pada populasi umum tidak diketahui, namun 
terjadi pada $1-10 \%$ pasien rawat inap, dengan tingkat mortalitas 1 dari 1.000 pasien. Meskipun elektrokardiogram dapat menunjukkan perubahan yang menandakan hiperkalemia, diagnosis biasanya didasarkan pada hasil laboratorium. Hiperkalemia dapat dikaitkan dengan kelainan elektrokardiografi yang sering terjadi. Secara umum, hiperkalemia menghasilkan penurunan kecepatan rangsangan dan konduksi secara bertahap pada sel pacu jantung dan jaringan di seluruh jantung. Temuan khas elektrokardiogram dalam perkembangan hiperkalemia dari gelombang T yang tinggi dan "memuncak" dan interval QT yang diperpendek menjadi perpanjangan interval PR dan hilangnya gelombang $\mathrm{P}$, dan kemudian pelebaran kompleks QRS, yang berpuncak pada morfologi "gelombang sinus" dan kematian jika tidak diobati. Tingkat kalium serum yang tinggi dianggap mengganggu konduksi pada serat Purkinje dan ventrikel lebih dari pada nodus AV. Sehingga bisa menimbulkan AV Block. ${ }^{14}$

\section{SIMPULAN}

Hasil elektrokardiogram didapatkan kesan hipertrofi ventrikel kiri dengan aksis normal. Sedangkan pada simpulan ekokardiografi didapatkan SA berat dan MR sedang, dengan EF 55\%, LA dan LV dilatasi dan LVH konsentrik.

Berdasarkan alur manajemen stenosis aorta dan 2017 ESC/EACTS Guidelines for the management of valvular heart disease, pasien ini direncanakan untuk angiografi. Jika dari hasil angiografi didapatkan ada penyumbatan pembuluh darah koroner jantung, disarankan AVR sekaligus CABG. Risiko operasi pada pasien ini jika dilakukan AVR sekaligus CABG berdasarkan STS Adult Cardiac Surgery adalah 4,162\%. Jika dari hasil angiografi tidak didapatkan penyumbatan pembuluh darah koroner jantung, disarankan untuk AVR. Risiko operasi pada pasien ini jika dilakukan AVR berdasarkan STS Adult Cardiac Surgery adalah 3,202\%.

\section{DAFTAR PUSTAKA}

1. Vahanian A, Alfieri O, Andreotti F, Antunes MJ, Baron-Esquivias G, Baumgartner H, et al. Guidelines on the management of valvular heart disease (version 2012): the Joint Task Force on the Management of Valvular Heart Disease of the European Society of Cardiology (ESC) and the European Association for Cardio-Thoracic Surgery (EACTS). Eur J Cardiothorac Surg. 2012; 42(4):S1-44. doi: 10.1093/ejcts/ezs455.

2. Rajamannan NM. Calcific Aortic Stenosis: Lessons learned from experimental and clinical studies. atheroscler thromb vasc biol. 2009; 29(2):162-8. doi: 10.1161/ATVBAHA.107.156752.

3. Awtry E, Davidoff R. Low-flow/low-gradient aortic stenosis. Circulation. 2011; 124(23):e739e741. 10.1161/CIRCULATIONAHA.111.075853. 
4. Fang J, O'Gara P. The history and physical examination. In: Mann D, Zipes D, Libby P, Bonow R, eds. Braunwald's Heart Disease: A Textbook of Cardiovascular Medicine. $8^{\text {th }}$ Edition.

Philadelphia: Saunders Elsevier; 2008.

5. European Society of G, Association for European Paediatric C, German Society for Gender M, Authors/Task Force M, Regitz-Zagrosek V, Blomstrom Lundqvist C, et al. ESC Guidelines on the management of cardiovascular diseases during pregnancy: the Task Force on the Management of Cardiovascular Diseases during Pregnancy of the European Society of Cardiology (ESC). Eur Heart J. 2011; 32:3147-97. doi: 10.1093/eurheartj/ehr218.

6. Nishimura RA, Otto CM, Bonow RO, Carabello BA, Erwin JP III, Guyton RA, et al. ACC/AHA 2014 Guidelines for the management of patients with valvular heart disease: executive summary: a report of the American College of Cardiology/American Heart Association Task Force on Practice Guidelines. Circulation. 2014; 129:2440-2492. doi: 10.1161/CIR.0000000000000029.

7. Holmes DR Jr, Mohr F, Hamm CW, Mack MJ. Venn diagrams in cardiovascular disease: The Heart team concept. Eur Heart J. 2014; 35(2):66-8. doi: 10.1093/eurheartj/ehs466.

8. Holmes DR Jr., Mack MJ, Kaul S, Agnihotri A, Alexander KP, Bailey SR, et al. ACCF/AATS/SCAI/STS expert consensus document on transcatheter aortic valve replacement. J Am Coll Cardiol 2012; 59(13):1200-54. doi: 10.1016/j.jacc.2012.01.001.

9. Rosenhek R, Binder T, Porenta G, Lang I, Christ G, Schemper M, et al. Predictors of outcome in severe, asymptomatic aortic stenosis. N Engl J Med. 2000; 343(9):611-17. doi: 10.1056/NEJM200008313430903.

10. Carabello BA. How does the heart respond to Aortic Stenosis: Let me count the ways. Circulation: Cardiovascular Imaging. 2013; 6:858-60. doi: 10.1161/CIRCIMAGING.113.001242.

11. Monin JL, Lancellotti P, Monchi M, Lim P, Weiss E, Piérard L, et al. Risk score predicting outcome in patients with asymptomatic aortic stenosis. Circulation. 2009; 120(1):69-75. doi: 10.1161/CIRCULATIONAHA.108.808857.

12. Baumgartner H, Falk V, Bax JJ, De Bonis M, Hamm C, Holm PJ, et al. 2017 ESC/EACTS Guidelines for the management of valvular heart disease. Eur Heart J. 2017; 38(36):2739-2791. doi: 10.1093/eurheartj/ehx391.

13. Yunaidi Y, Hermanto DY, Rahajoe AU. Buku Ajar Kardiovaskuler. Jakarta: Sagung Seto; 2017.

14. Chan TC, Brady WJ, Harrigan RA, Ornato JP, Rosen P. ECG in Emergency Medicine and Acute Care. Philadelphia: Mosby; 2005. doi: 10.1016/B978-0-323-01811-1.X5001-9. 